\title{
Value of plasma chloride concentration and acid-base status in the differential diagnosis of hyperpara- thyroidism from other causes of hypercalcaemia
}

\author{
M. R. WILLS \\ From the Department of Chemical Pathology, Royal Free Hospital, Lawn Road, London
}

SYNOPSIS A study is reported of the estimation of plasma chloride concentration and acid-base status in the differentiation of primary hyperparathyroidism from all other causes of hypercalcaemia. In the two groups of patients studied, all of whom had hypercalcaemia, there was complete separation between the two groups on the basis of plasma chloride concentration and acid-base status. In 16 patients with primary hyperparathyroidism the increase in plasma chloride concentration and associated metabolic acidosis could have been accounted for by the known renal tubular effects of parathyroid hormone. In 13 patients with hypercalcaemia due to various other causes the decrease in plasma chloride concentration and associated metabolic alkalosis could be accounted for either by the known effects of an excess of calcium-ion on the renal tubules, or perhaps by suppression of endogenous parathyroid hormone secretion. In patients with hypercalcaemia and hypophosphataemia of 'pseudohyperparathyroidism' associated with non-endocrine tumours it is postulated that the low plasma chloride concentrations and metabolic alkalosis found in these patients were due either to a differing biological activity of the parathyroid-hormone-like polypeptide secreted by the tumour cells, or possibly to simultaneous secretion by these cells of an ACTH-like polypeptide.

Confirmation of the diagnosis of primary hyperparathyroidism has been classically based on the finding of hypercalcaemia in association with a low plasma phosphorus concentration (Albright and Reifenstein, 1948). Hypophosphataemia, however, occurs in only approximately one half of all patients with primary hyperparathyroidism (Pyrah, Hodgkinson, and Anderson, 1966; Strott and Nugent, 1968), and also occurs in hypercalcaemic states other than primary hyperparathyroidism (Strott and Nugent, 1968). We previously reported that the plasma chloride concentration was significantly higher in patients with primary hyperparathyroidism when compared with patients with hypercalcaemia due to other causes, and that there was almost complete separation of the two groups on this basis (Wills and McGowan, 1963; Wills, 1964; Wills and McGowan, 1964a). These findings have since been confirmed by other workers (Heinemann, 1965; Pyrah et al, 1966; Lafferty, 1966; Heffernan and Carty, 1969). Howard and his colleagues had suggested that the plasma bicarbonate concentration tended to be normal or low in patients with primary hyperparathyroidism, Received for publication 30 July 1970. and was often high in patients with hypercalcaemia due to other causes (Thomas, Connor, and Morgan, 1958; Howard, 1962). Such changes were presumably the reciprocal of the changes in plasma chloride concentration. The aetiological mechanism for these findings was considered to represent a fundamental disturbance in the homeostatic acid-base control mechanisms of hypercalcaemic patients (Wills, 1964).

This paper reports a study of electrolyte and acidbase status in patients with hypercalcaemia, due to both primary hyperparathyroidism and various other causes, and the value of these variables in the differential diagnosis of the hypercalcaemia of primary hyperparathyroidism from that due to all other causes.

\section{Subjects and Patients Studied}

NORMAL SUBJECTS

Twelve normal subjects were studied: all were volunteers, and were either medical students or laboratory workers. All were healthy and had no evidence of a disturbance of calcium homeostasis. 
The group, whose ages ranged from 21 to 36 years, comprised eight males and four females.

\section{HYPERPARATHYROID PATIENTS}

Sixteen patients with hypercalcaemia due to primary hyperparathyroidism were studied; in all of these the diagnosis was later proven by surgical exploration of the neck and histological examination of the adenoma.

\section{HYPERCALCAEMIC PATIENTS}

Thirteen patients with hypercalcaemia due to causes other than primary hyperparathyroidism werestudied. The final diagnoses in these patients were carcinoma (5), vitamin D overdose (3), multiple myelomatosis (3), sarcoidosis (1), and Paget's disease (1). In four of the patients with carcinoma the hypercalcaemia was associated with osteolytic bone metastases from a primary carcinoma in the breast. In the fifth patient the hypercalcaemia was associated with a squamous-cell carcinoma of the bronchus, and in this patient there were no bone metastases seen on extensive radiographic survey. This patient may be classified as a case of 'pseudo-hyperparathyroidism' due to the secretion of a parathyroid-like polypeptide by a non-endocrine tumour.

\section{Methods}

All estimations were performed on 'arterializedvenous' blood specimens which were collected by the author. The samples were drawn from the back of the hand, after immersion in water (approximately $50^{\circ} \mathrm{C}$ ) for a minimum time of five minutes. The samples were collected anaerobically, without stasis, into a plastic syringe, the dead space of which was filled with heparin (Evans heparin 1,000 units per $\mathrm{ml}$ ).

$p \mathrm{H}$ measurements were made on whole blood at $37^{\circ} \mathrm{C}$ with a capillary glass electrode (E.I.L. ${ }^{1}$ model SHH 33).

$\mathrm{PCO}_{2}$ measurements were made on whole blood using a Severinghaus $\mathrm{PCO}_{\mathbf{z}}$ electrode (E.I.L. ${ }^{1}$ model 9987 100).

Plasma bicarbonate concentrations were measured on a Natelson micro-gasometer (Natelson, 1951).

Plasma calcium concentration (total) was measured in a few of the earlier patients by the method of Wills and Gray (1964) and in the majority of the patients and all the normal subjects by the method of Lewin, Wills, and Baron (1969).

Plasma phosphorus concentration was estimated by the method of Fiske and Subbarow (1925).

Total plasma proteins were estimated by the biuret method of Wolfson, Cohn, Calvary, and Ichiba (1948).

'Electronic Instruments Ltd, Richmond, Surrey
Blood urea concentrations were measured by a diacetyl monoxime method on the AutoAnalyzer (method file $\mathrm{N}-1 \mathrm{C}$ ).

Plasma sodium and potassium concentrations were estimated by flame photometry (EEL ${ }^{2}$ clinical flame photometer model 150).

Plasma chloride concentrations were measured colorimetrically with an $\mathrm{EEL}^{2}$ chloride meter.

\section{Results}

The full results obtained in the patients with hypercalcaemia due to primary hyperparathyroidism and in those with hypercalcaemia due to various other causes are given in Tables I and II respectively. The tables also show the values of the mean \pm SD for the normal subjects, their comparison with the patients by Student's $t$ index, and the significance (P) of the $t$ values. In both groups of patients the mean blood urea concentrations were higher than in the normal subjects; in view of the skew nature of the distribution of the values they have not been compared statistically. A comparison by Student's t index of the two patient groups is shown in Table III, together with the significance (P) of the $t$ values.

In neither of the groups of patients was there a significant difference for the plasma phosphorus concentrations when compared with the normal subjects. In the patients with primary hyperparathyroidism the mean $( \pm$ SD) plasma phosphorus concentration was $2.81( \pm 0.78) \mathrm{mg}$ per $100 \mathrm{ml}$, which differed significantly from the mean $( \pm S D)$ of $3.54( \pm 0.98) \mathrm{mg}$ per $100 \mathrm{ml}$ for the patients with hypercalcaemia due to various other causes. The individual results for plasma phosphorus concentration in these two groups are shown plotted against plasma calcium concentration in Figure 1. Figure 1 shows that although the mean values for the two groups differed significantly there was no clear-cut difference for the individual values between the two groups on the basis of plasma phosphorus concentration. The failure to demonstrate hypophosphataemia in all of the patients with primary hyperparathyroidism was probably, in part, due to renal damage, as in this group the mean blood urea concentration was higher than in the group of normal subjects. There was also a difference between the two groups of patients for the mean blood urea concentration with a higher value in the group of patients with hypercalcaemia when compared with the patients with primary hyperparathyroidism.

There was a significant difference in the plasma chloride concentration between the two groups of patients, and between both of the groups of patients when compared individually with the normal subjects. 'Evans Electroselenium Ltd, Halstead, Surrey 


\begin{tabular}{|c|c|c|c|c|c|c|c|c|c|c|c|c|}
\hline \multirow{2}{*}{$\begin{array}{l}\text { Cases with } \\
\text { Primary } \\
\text { Hyper- } \\
\text { thyroidism }\end{array}$} & \multicolumn{2}{|c|}{ Plasma $(\mathrm{mg} / 100 \mathrm{ml})$} & \multirow{2}{*}{$\begin{array}{l}\text { Blood } \\
\text { Urea } \\
\text { s(mg/100 } \\
m l)\end{array}$} & \multirow{2}{*}{$\begin{array}{l}\text { Plasma } \\
\text { Total } \\
\text { Protein } \\
(\mathrm{g} / 100 \mathrm{ml})\end{array}$} & \multicolumn{4}{|c|}{ Plasma (m-equiv/l) } & \multirow{2}{*}{$\begin{array}{l}\mathrm{PCO}_{2} \\
\mathrm{mmHg}\end{array}$} & \multirow[t]{2}{*}{$p H$} & \multirow[t]{2}{*}{ Bones } & \multirow[t]{2}{*}{ Stones } \\
\hline & Calcium & Phosphorus & & & Sodium & Potassium & Chloride & $\begin{array}{l}\text { Bicarbon- } \\
\text { ate }\end{array}$ & & & & \\
\hline 1 & $12 \cdot 1$ & 2.9 & 20 & 6.9 & 140 & $4 \cdot 0$ & 110 & $22 \cdot 0$ & 40.5 & $7 \cdot 36$ & - & + \\
\hline 2 & $11 \cdot 4$ & $3 \cdot 8$ & 125 & $7 \cdot 2$ & 135 & $5 \cdot 0$ & 109 & $19 \cdot 5$ & $39 \cdot 5$ & $7 \cdot 33$ & + & - \\
\hline 3 & $11 \cdot 0$ & 2.9 & 46 & $6 \cdot \overline{5}$ & 144 & $4 \cdot 1$ & 112 & $23 \cdot 5$ & $42 \cdot 5$ & $7 \cdot 37$ & - & + \\
\hline 4 & $13 \cdot 1$ & $2 \cdot 4$ & 65 & $6 \cdot 1$ & 137 & $4 \cdot 8$ & 98 & $21 \cdot 5$ & $37 \cdot 5$ & $7 \cdot 39$ & + & - \\
\hline 5 & 11.0 & $3 \cdot 1$ & 47 & $7 \cdot 2$ & 131 & $4 \cdot 3$ & 103 & $22 \cdot 5$ & $39 \cdot 5$ & $7 \cdot 38$ & - & + \\
\hline 6 & $11 \cdot 6$ & $1 \cdot 5$ & 34 & $7 \cdot 2$ & 140 & $5 \cdot 2$ & 116 & $15 \cdot 0$ & $32 \cdot 0$ & $7 \cdot 34$ & - & + \\
\hline 7 & $11 \cdot 6$ & 3.0 & 48 & $6 \cdot 5$ & 139 & $4 \cdot 2$ & 105 & 25.0 & $44 \cdot 0$ & $7 \cdot 35$ & - & + \\
\hline 8 & $13 \cdot 3$ & $2 \cdot 2$ & 16 & $7 \cdot 4$ & 138 & 2.9 & 104 & $19 \cdot 5$ & $45 \cdot 5$ & $7 \cdot 25$ & + & - \\
\hline 9 & $12 \cdot 4$ & $3 \cdot 4$ & 30 & 6.7 & 132 & $4 \cdot 7$ & 102 & $18 \cdot 5$ & $35 \cdot 0$ & $7 \cdot 34$ & - & + \\
\hline 10 & $11 \cdot 5$ & $2 \cdot 7$ & 32 & $6 \cdot 4$ & 139 & $4 \cdot 3$ & 107 & $22 \cdot 0$ & $39 \cdot 5$ & $7 \cdot 36$ & - & + \\
\hline 11 & 14.0 & $2 \cdot 6$ & 46 & 6.8 & 147 & $4 \cdot 3$ & 110 & 24.0 & $42 \cdot 0$ & $7 \cdot 40$ & + & - \\
\hline 12 & $12 \cdot 5$ & $2 \cdot 0$ & 25 & $9 \cdot 4$ & 137 & 3.6 & 107 & $22 \cdot 5$ & $38 \cdot 5$ & $7 \cdot 40$ & - & + \\
\hline 13 & $11 \cdot 5$ & $2 \cdot 6$ & 32 & $7 \cdot 5$ & 144 & $4 \cdot 1$ & 104 & $20 \cdot 5$ & $33 \cdot 0$ & $7 \cdot 38$ & + & - \\
\hline 14 & $16 \cdot 2$ & 4.9 & 84 & $6 \cdot 2$ & 137 & $5 \cdot 0$ & 106 & $19 \cdot 0$ & $31 \cdot 0$ & $7 \cdot 40$ & + & - \\
\hline 15 & $12 \cdot 1$ & $2 \cdot 5$ & 30 & $6 \cdot 7$ & 150 & $4 \cdot 8$ & 118 & $20 \cdot 0$ & $42 \cdot 0$ & $7 \cdot 35$ & + & - \\
\hline 16 & $11 \cdot 5$ & $2 \cdot 4$ & 36 & $7 \cdot 0$ & 131 & $4 \cdot 1$ & 100 & $20 \cdot 0$ & $44 \cdot 5$ & $7 \cdot 30$ & - & + \\
\hline Mean & $12 \cdot 30$ & $2 \cdot 81$ & $44 \cdot 8$ & $6 \cdot 98$ & $138 \cdot 8$ & $4 \cdot 34$ & 106.9 & 20.94 & $39 \cdot 16$ & $7 \cdot 356$ & & \\
\hline$\pm \mathbf{S D}$ & $\pm 1 \cdot 34$ & $\pm 0 \cdot 78$ & $\pm 27 \cdot 3$ & \pm 0.77 & \pm 5.6 & \pm 0.60 & $\pm \quad 5.4$ & $\pm 2 \cdot 46$ & $\pm 4 \cdot 46$ & \pm 0.039 & & \\
\hline \multicolumn{13}{|c|}{ Normal Subjects } \\
\hline Mean & $9 \cdot 25$ & $3 \cdot 25$ & $26 \cdot 9$ & $7 \cdot 17$ & $136 \cdot 3$ & $4 \cdot 22$ & 99.6 & $22 \cdot 75$ & $38 \cdot 21$ & $7 \cdot 393$ & & \\
\hline$\pm \mathbf{S D}$ & \pm 0.33 & \pm 0.52 & $\pm 5 \cdot 3$ & $\pm 0 \cdot 26$ & $\pm \quad 2.5$ & $\pm 0 \cdot 37$ & $\pm \quad 3 \cdot 0$ & \pm 1.01 & \pm 1.99 & \pm 0.010 & - & - \\
\hline $\overrightarrow{\mathbf{P}}$ & $<0.001$ & $>0.1$ & & $>0.4$ & $>0.1$ & $>0.6$ & $<0.001$ & $<0.05$ & $>0.5$ & $>0.01$ & & \\
\hline
\end{tabular}

Table I Results in 16 patients with primary hyperparathyroidism and mean $\pm S D$ values for 12 normal subjects ${ }^{1}$ ${ }^{1}$ Comparison of the two groups by Student's $t$ index and significance $(P)$ of the $t$ values

\begin{tabular}{|c|c|c|c|c|c|c|c|c|c|c|}
\hline \multirow[t]{2}{*}{ Patient and Diagnosis } & \multicolumn{2}{|c|}{ Plasma $(\mathrm{mg} / 100 \mathrm{ml})$} & \multirow{2}{*}{$\begin{array}{l}\text { Blood Urea } \\
(\mathrm{mg} / 100 \mathrm{ml})\end{array}$} & \multirow{2}{*}{$\begin{array}{l}\text { Plasma } \\
\text { Total } \\
\text { Protein } \\
(\mathrm{g} / 100 \mathrm{ml})\end{array}$} & \multicolumn{4}{|c|}{ Plasma (m-equiv/l) } & \multirow{2}{*}{$\begin{array}{l}\mathrm{PCO}_{2} \\
(\mathrm{mmHg})\end{array}$} & \multirow[t]{2}{*}{ pH } \\
\hline & Calcium & Phosphorus & & & Sodium & Potassium & Chloride & Bicarbonate & & \\
\hline
\end{tabular}

\begin{tabular}{|c|c|c|c|c|c|c|c|c|c|c|}
\hline \multicolumn{11}{|l|}{ Hypercalcaemic } \\
\hline A Carcinoma 1 & $13 \cdot 2$ & $3 \cdot 3$ & 52 & $6 \cdot 8$ & 140 & $4 \cdot 0$ & 96 & $29 \cdot 0$ & $40 \cdot 0$ & $7 \cdot 49$ \\
\hline B Carcinomatosis 2 & $14 \cdot 0$ & $3 \cdot 4$ & 124 & 7.9 & 130 & $4 \cdot 3$ & 91 & $26 \cdot 0$ & $44 \cdot 0$ & $7 \cdot 42$ \\
\hline C Carcinomatosis ${ }^{2}$ & $11 \cdot 2$ & 2.9 & 106 & $5 \cdot 7$ & 137 & $4 \cdot 4$ & 95 & $23 \cdot 0$ & $39 \cdot 0$ & $7 \cdot 42$ \\
\hline D Carcinomatosis ${ }^{2}$ & $11 \cdot 2$ & $3 \cdot 2$ & 90 & $7 \cdot 2$ & 137 & $3 \cdot 7$ & 95 & $24 \cdot 0$ & $42 \cdot 0$ & $7 \cdot 42$ \\
\hline E Carcinomatosis ${ }^{2}$ & $11 \cdot 5$ & $2 \cdot 4$ & 58 & $6 \cdot 0$ & 130 & 3.4 & 91 & $26 \cdot 0$ & $43 \cdot 5$ & $7 \cdot 43$ \\
\hline F Vitamin D overdose & $13 \cdot 7$ & $2 \cdot 6$ & 64 & $7 \cdot 5$ & 139 & $3 \cdot 9$ & 84 & $33 \cdot 5$ & $42 \cdot 0$ & $7 \cdot 53$ \\
\hline G Vitamin D overdose & $14 \cdot 5$ & $2 \cdot 7$ & 58 & $6 \cdot 7$ & 137 & $2 \cdot 9$ & 93 & $28 \cdot 5$ & $41 \cdot 0$ & $7 \cdot 48$ \\
\hline H Vitamin D overdose & $12 \cdot 8$ & $4 \cdot 5$ & 142 & $6 \cdot 7$ & 137 & $4 \cdot 2$ & 95 & $36 \cdot 0$ & $47 \cdot 5$ & $7 \cdot 55$ \\
\hline I Myelomatosis & $15 \cdot 7$ & $4 \cdot 0$ & 68 & $13 \cdot 0$ & 127 & $3 \cdot \overline{8}$ & 90 & $29 \cdot 0$ & $42 \cdot 0$ & $7 \cdot 49$ \\
\hline J Myelomatosis & 10.9 & $5 \cdot 8$ & 58 & $8 \cdot 7$ & 140 & $4 \cdot 7$ & 101 & $28 \cdot 0$ & $43 \cdot 0$ & $7 \cdot 46$ \\
\hline K Myelomatosis & $13 \cdot 2$ & $4 \cdot 2$ & 104 & $8 \cdot 5$ & 129 & $4 \cdot 0$ & 92 & $23 \cdot 0$ & $43 \cdot 5$ & $7 \cdot 42$ \\
\hline L Sarcoidosis & $14 \cdot 5$ & $2 \cdot 5$ & 100 & $7 \cdot 0$ & 140 & $3 \cdot 8$ & 94 & $23 \cdot 5$ & $39 \cdot 0$ & $7 \cdot 44$ \\
\hline M Paget's disease & $11 \cdot 2$ & $4 \cdot 0$ & 44 & $6 \cdot 5$ & 139 & $4 \cdot 2$ & 101 & $26 \cdot 0$ & $42 \cdot 0$ & $7 \cdot 44$ \\
\hline Mean & $12 \cdot 89$ & $3 \cdot 54$ & $82 \cdot 2$ & $7 \cdot 55$ & $135 \cdot 5$ & 3.95 & $93 \cdot 7$ & $27 \cdot 35$ & $42 \cdot 19$ & $7 \cdot 461$ \\
\hline \pm SD & \pm 1.57 & \pm 0.98 & $\pm 30 \cdot 8$ & $\pm 1 \cdot 86$ & $\pm 4 \cdot 7$ & \pm 0.46 & \pm 4.5 & \pm 3.97 & $\pm 2 \cdot 26$ & \pm 0.044 \\
\hline \multicolumn{11}{|l|}{ Normal Subjects } \\
\hline \multirow{3}{*}{$\begin{array}{l}\text { Mean } \\
\pm \text { SD } \\
\mathbf{P}\end{array}$} & $9 \cdot 25$ & $3 \cdot 25$ & 26.9 & $7 \cdot 17$ & $136 \cdot 3$ & $4 \cdot 22$ & 99.6 & $22 \cdot 75$ & $38 \cdot 21$ & \multirow{3}{*}{$\begin{array}{r}7.393 \\
\pm 0.010 \\
<0.001\end{array}$} \\
\hline & \pm 0.33 & \pm 0.52 & $\pm 5 \cdot 3$ & $\pm 0 \cdot 26$ & \pm 2.5 & \pm 0.37 & $\pm \mathbf{3 . 0}$ & \pm 1.01 & \pm 1.99 & \\
\hline & $<0.001$ & $>0.3$ & & $>0.4$ & $>0.6$ & $>0.1$ & $<0.001$ & $<0.001$ & $<0.001$ & \\
\hline
\end{tabular}

Table II Results in 13 patients with hypercalcaemia of various causes and mean $\pm S D$ values for 12 normal subjects ${ }^{3}$

'Primary carcinoma in bronchus (squamous-cell)

'Primary carcinoma in breast

${ }^{3}$ Comparison of the two groups by Student's $t$ index and significance $(P)$ of the $t$ values

In the patients with primary hyperparathyroidism the mean $( \pm S D)$ plasma chloride concentration of $106.9( \pm 5.4)$ m-equiv per litre was significantly higher than the mean $( \pm$ SD) of $99.6( \pm 3.0)$ m-equiv per litre found in the patients with hypercalcaemia due to various other causes. The individual results for plasma chloride concentration in these two groups show an almost clear-cut separation between them at a concentration of 102 m-equiv per litre. Among the 16 patients with primary hyperparathyroidism there were two patients with values below that concentration, and none of the values in the 13 patients with hypercalcaemia due to various other causes were above that concentration. 


\begin{tabular}{lccl}
\hline & $\begin{array}{l}\text { Primary } \\
\text { Hyper- } \\
\text { thyroidism }\end{array}$ & $\begin{array}{l}\text { Hyper- } \\
\text { calcaemia }\end{array}$ & $\mathrm{P}$ \\
\hline No. & 16 & 13 & - \\
pH & 7.356 & $7 \cdot 461$ & $<0.001$ \\
PCO $_{3}$ (mmHg) & $39 \cdot 16$ & 42.17 & $<0.05$ \\
Bicarbonate (m-equiv/l) & 20.94 & 27.35 & $<0.001$ \\
Calcium (mg/100 ml) & 12.30 & 12.89 & $>0.2$ \\
Phosphorus (mg/100 ml) & 2.81 & 3.54 & $<0.05$ \\
Total protein (g/100 ml) & 6.98 & 7.55 & $>0.2$ \\
Sodium (m-equiv/l) & 138.8 & 135.5 & $>0.05$ \\
Potassium (m-equiv/l) & 4.34 & 3.95 & $>0.05$ \\
Chloride (m-equiv/l) & 106.9 & 93.7 & $<0.001$ \\
\hline
\end{tabular}

Table III Mean values for 16 patients with primary hyperparathyroidism and 13 with hypercalcaemia due to various other causes 1

'Comparison of the two groups by Student's $t$ index and significance (P) of $t$ values

The difference in the mean plasma chloride concentration between the two groups of patients was 13.2 m-equiv per litre (Table III), and was in the main part accounted for by the significant difference in the plasma bicarbonate concentration of 6.41 m-equiv per litre. The remaining 'gap' was accounted for, in part, by the differences in mean sodium (3.3 m-equiv per litre), potassium $(0.34$ m-equiv per litre), phosphorus $(0.73 \mathrm{mg}$ per $100 \mathrm{ml}$ $\equiv 0.42$ m-equiv per litre), and protein concentration $(0.57 \mathrm{~g}$ per $100 \mathrm{ml} \equiv 1.38 \mathrm{~m}$-equiv per litre), although these differences, with the exception of that for phosphorus, between the two groups were not significant. The absence of a greater increase in the plasma bicarbonate concentrations in the non- hyperparathyroid patients was presumably due to the accumulation of 'organic acid' metabolites, due to renal insufficiency, which was reflected in the higher blood urea concentrations in this group when compared with both the normal subjects and the patients with primary hyperparathyroidism.

The changes in plasma chloride concentration were predominantly represented by a difference in acid-base status between the two groups of patients, and also on comparison with the normal subjects. In the patients with primary hyperparathyroidism the values for both blood $p \mathrm{H}, \mathrm{PCO}_{2}$, and bicarbonate concentrations were significantly lower (Table III) than those found in the patients with hypercalcaemia due to other causes. The individual results for blood $p \mathrm{H}, \mathrm{PCO}_{2}$, and plasma bicarbonate concentration for the two groups of patients are shown plotted in Figure 2. It can be seen from Fig. 2 that there was a clear-cut difference between the two groups on a basis of blood $p \mathrm{H}$, with an overlap between the two groups in respect of the $\mathrm{PCO}_{2}$ values, and less marked overlap for the plasma bicarbonate concentrations.

\section{Discussion}

In the patients reported here, all of whom had hypercalcaemia, there was complete separation between those with hypercalcaemia due to primary hyperparathyroidism and those with hypercalcaemia due to all other causes on the basis of plasma chloride concentration and acid-base status. The changes in plasma chloride concentration are in accordance

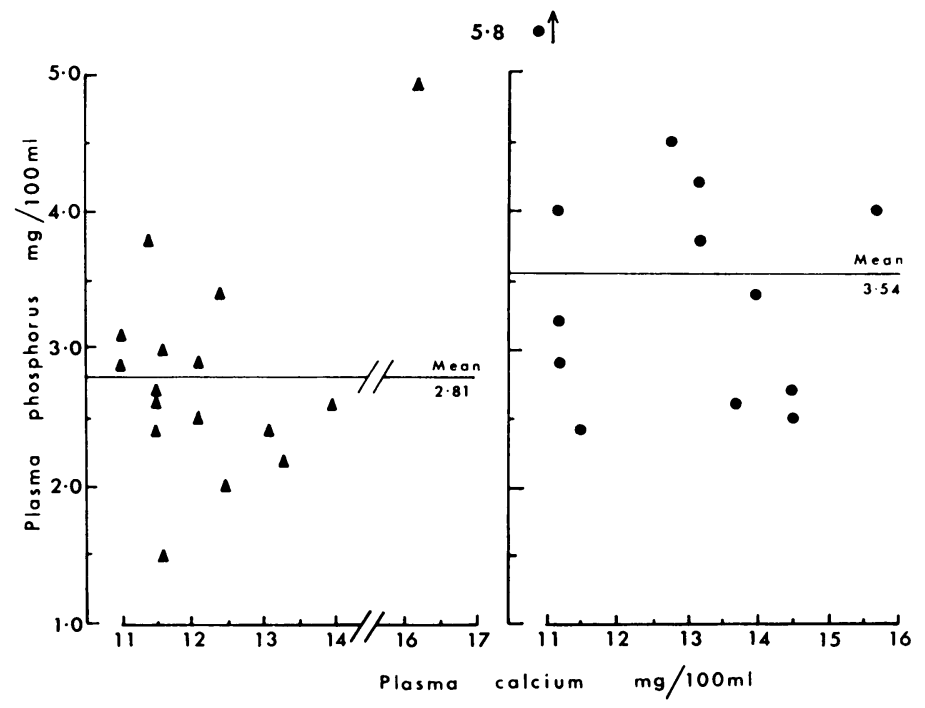

Fig. 1 Plasma concentrations of calcium plotted against phosphorus for 16 patients with primary hyperparathyroidism $(\mathbf{\Delta})$ and 13 with hypercalcaemia (O) due to various other causes. 


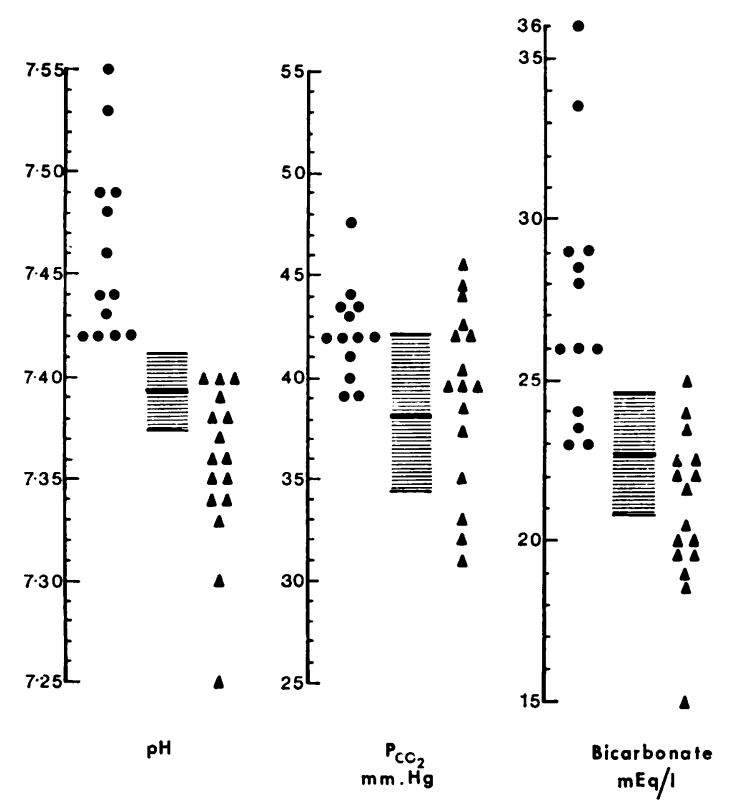

Fig. 2 Values for blood $\mathrm{pH}, \mathrm{PCO}_{2}$, and plasma bicarbonate concentrations for 16 patients with primary hyperparathyroidism (A) and 13 with hypercalcaemia (O) due to other causes. Also shown is the normal range (mean $\pm 2 S D$ ) determined from results in 12 normal subjects.

with our previously reported studies (Wills and McGowan, 1963; Wills, 1964; Wills and McGowan, 1964a). The changes in plasma chloride concentrations were associated with a metabolic alkalosis in the patients with hypercalcaemia due to causes other than primary hyperparathyroidism and a metabolic acidosis in the latter group, which confirms our preliminary report (Wills and McGowan, 1964b), although of the patients with primary hyperparathyroidism six of them had blood $p H$ values within the lower half of the range obtained in the normal subjects.

In order to account for changes in acid-base status and plasma chloride concentrations, which ranged in the latter case from normal to high values in the hyperparathyroid group and from normal to low values in the other group, it is necessary to invoke at least two separate factors, one causing a rise and the other causing a fall in plasma chloride concentration. There are several factors which cause changes in plasma chloride concentration with a reciprocal change in bicarbonate concentration and acid-base status, and the case histories of all the patients were examined for the presence of these factors.
FACTORS CAUSING AN INCREASE IN PLASMA
CHLORIDE CONCENTRATION

\section{Chloride administration}

Chlorides were not prescribed for any patient. No information was available about dietary salt intake, and no measurements were made of urinary chloride excretion.

\section{Respiratory alkalosis}

Respiratory alkalosis is associated with a fall of plasma $\mathrm{PCO}_{2}$, a compensatory fall of plasma bicarbonate with a reciprocal rise of plasma chloride concentration. The acid-base findings exclude this as an aetiological factor.

\section{Renal tubular acidosis}

This is associated with a relative inability to secrete an acid urine so that an acidosis develops with a fall in plasma bicarbonate and a reciprocal rise in plasma chloride.

\section{FACTORS CAUSING A REDUCTION IN PLASMA CHLORIDE CONCENTRATION}

\section{Vomiting}

Vomiting was not reported in any of the patients with primary hyperparathyroidism, and in only three of the other hypercalcaemic patients (cases F, I, and L). In only one of these (case F) was it severe and probably accounts, in part, for the low plasma chloride concentration ( 84 m-equiv per litre) found in this patient.

\section{Alkali administration}

None of the patients in either group was either being given alkalis or was noted as having taken 'antacids'.

\section{Potassium depletion.}

The difference in the mean potassium concentration was small and in no way could account for the difference between the two groups.

\section{Bone rarefaction}

Bone salts are relatively alkaline and release of bone salts may be a factor in causing low chloride values.

\section{Renal tubular alkalosis}

There is evidence that hypercalcaemia causes the excretion of a relatively more acid urine and such an action, if continued for some time, could be expected to cause a metabolic alkalosis.

\section{Respiratory acidosis}

This is associated with a rise of $\mathrm{PCO}_{2}$, a compensatory fall of plasma bicarbonate with a reciprocal rise in chloride concentration. There was no clinical 
evidence to suggest that this factor was operative in either group, which is also excluded by the acid-base findings.

From a consideration of these factors it would appear that the changes in plasma chloride concentration and acid-base status are due either to some alteration at the renal tubular level or are possibly related to the liberation of bone salt. Heinemann (1965) postulated that the metabolic alkalosis, found in patients with hypercalcaemia due to neoplastic disease, was due to the increased liberation of phosphate base from bone. In the hyperparathyroid patients with bone disease bone salts would presumably also be released, and the higher plasma chloride concentrations in this group may simply be due to the opposing action of a renal tubular acidosis. It is also possible that in these patients the rate of bone resorption is relatively slower than that in the patients with hypercalcaemia due to other causes. If release of bone salts was a major factor in the aetiology of the chloride and acid-base changes, a difference would be expected between the patients with bone disease in primary hyperparathyroidism when compared with those with renal stones. A comparison of the mean values for $p \mathrm{H}, \mathrm{PCO}_{2}$, bicarbonate, and chloride concentration between these two types of primary hyperparathyroidism is shown in Table IV; there was no significant difference between any of these variables in the patients studied. It would seem doubtful, therefore, that liberation of bone salt is of importance as an aetiological mechanism for these observations.

\begin{tabular}{lccl}
\hline & $\begin{array}{l}\text { Bone } \\
\text { Disease }\end{array}$ & $\begin{array}{l}\text { Renal } \\
\text { Stones }\end{array}$ & $\mathbf{P}$ \\
\hline $\mathrm{No.}$ & 7 & 9 & - \\
$p \mathrm{H}$ & $7 \cdot 357$ & $7 \cdot 356$ & $>0.9$ \\
$\mathrm{PCO}_{2}(\mathrm{mmHg})$ & 38.64 & 39.56 & $>0.6$ \\
Bicarbonate (m-equiv/l) & 20.57 & 21.22 & $>0.6$ \\
Chloride (m-equiv/l) & 107.0 & 106.9 & $>0.9$
\end{tabular}

Table IV Mean values in patients with primary

hyperparathyroidism classified according to clinical presentation $^{1}$

${ }^{1}$ Comparison of the two groups by Student's $t$ index and significance (P) of the $t$ values

The most likely explanation is therefore that the findings in the patients with primary hyperparathyroidism are due to an action of the parathyroid hormone on the renal tubular cells producing a hyperchloraemic acidosis. This explanation is supported by experimental work showing that the injection of parathyroid extract, or of purified parathyroid hormone, causes the urine to become more alkaline (Nordin, 1960; Hellman, Au, and Bartter, 1965). Hellman et al (1965) studied the effects of the intravenous administration of parathyroid extract and of a purified parathyroid hormone on urinary acidification and on solute excretion in normal human subjects and thyro-parathyroidectomized dogs. In all their subjects there was an immediate rise in urinary $p \mathrm{H}$ and bicarbonate excretion with a fall in titrable-acid-minus-bicarbonate and ammonia following the intravenous injection, and this was usually associated with a rise in the urinary excretion of sodium and potassium. They considered that parathyroid hormone probably inhibited sodium for hydrogen-ion exchange in the renal tubules, perhaps by directly interfering with the ability of the kidney to maintain a hydrogen-ion gradient between the body fluids and the tubular urine. This tubular effect of parathyroid hormone on the hydrogen-ion gradient presumably accounts for the metabolic acidosis in the patients reported here.

The most likely explanation for the low plasma chloride concentration and alteration in acid-base status in the patients with hypercalcaemia due to causes other than primary hyperparathyroidism is renal tubular alkalosis. It has been shown that the acute intravenous infusion of calcium, either as chloride or gluconate, causes an increase in urinary hydrogen-ion excretion in both animals (Verbanck, 1965) and in man (Richet, Ardaillou, Amiel, and Lecestre, 1962 and 1963). Richet and his colleagues (1963) reported that following a single intravenous injection of calcium salt, either as chloride or gluconate, in 16 adults the mean urinary $p \mathrm{H}$ fell from 6.75 to 5.11 ; this change was rapid in onset and continued for more than four hours after the injection. They postulated that this effect was due to an activation of renal tubular carbonic anhydrase activity by calcium (Ardaillou, Amiel, Lecestre, and Richet, 1963). Such a factor, operating over a long period, could possibly cause a metabolic alkalosis of renal tubular origin. It is of considerable interest that in patients with hypocalcaemia due to hypoparathyroidism it has recently been reported that there is a metabolic alkalosis (Barzel, 1969) which was attributed to the absence of parathyroid hormone. Barzel proposed that in the absence of parathyroid hormone there might be a failure in either the tubular reabsorption of hydrogen ions and/or citric acid formation. These two factors either individually or in combination resulting in a reduction of extracellular hydrogen-ion concentration. Such a hypothesis could also be postulated as playing a role in the aetiology of the metabolic alkalosis found in the patients with hypercalcaemia due to causes other than hyperparathyroidism in whom, presumably, endogenous parathyroid hormone secretion would be suppressed. 
It is a possibility that calcitonin, which has an opposite action to parathyroid hormone on bone, may also have an opposite effect on the renal tubules and play a role in the production of the renal tubular alkalosis. On the kidney, however, calcitonin has a phosphaturic action similar to that of parathyroid hormone but does not affect the renal excretion of hydrogen ions in a reproducible manner (Ardaillou, Vuagnat, Milhaud, and Richet, 1967; Singer, Woodhouse, Parkinson, and Joplin, 1969; Cochran, Peacock, Sachs, and Nordin, 1970). Calcitonin would not appear therefore to play a role in the aetiology of metabolic alkalosis in the patients with hypercalcaemia due to causes other than primary hyperparathyroidism.

The biochemical combination of hypercalcaemia and hypophosphataemia may occur in patients with non-endocrine-tissue hormone-secreting tumours, and this has been termed 'pseudo-hyperparathyroidism' (Fry, 1962; Snedecor and Baker, 1964; Lafferty,
1966). Although immunologically similar to the naturally occurring hormone the parathyroid-likepolypeptide secreted by malignant tumours would appear to have some differing biological properties, as in these cases the hypercalcaemia is associated with a metabolic alkalosis. One of the patients reported here (case A) was classified as a case of 'pseudo-hyperparathyroidism'. The hypercalcaemia was associated with a low plasma chloride concentration and metabolic alkalosis (see Table II). All of these biochemical abnormalities returned to normal values after radiotherapy and regression in tumour size. Reports in the literature with full simultaneous details of electrolyte and acid-base status in patients with hypercalcaemia of 'pseudo-hyperparathyroidism', associated with non-endocrine tumours are relatively few, and those that have been reported are detailed in Table V. From an inspection of Table V it can be seen that in only two of the 19 cases reported did the plasma chloride concentration exceed a value

\begin{tabular}{|c|c|c|c|c|c|c|c|c|c|c|c|}
\hline \multirow[t]{2}{*}{ Reference } & \multirow[t]{2}{*}{ Diagnosis } & \multicolumn{7}{|l|}{ Plasma } & \multicolumn{3}{|l|}{ Blood } \\
\hline & & $\begin{array}{l}\text { Calcium } \\
(m g / 100\end{array}$ & $\begin{array}{l}\text { Phos- } \\
\text { phorus } \\
\text { ml) }\end{array}$ & $\begin{array}{l}\text { Total } \\
\text { Protein } \\
(\mathrm{g} / 100 \mathrm{ml})\end{array}$ & $\begin{array}{l}\mathrm{Na} \\
\text { (m-equiv }\end{array}$ & $\underset{v / l)}{K}$ & $\mathrm{Cl}$ & $\mathrm{HCO}_{3}$ & $p \mathrm{H}$ & $\begin{array}{l}\mathrm{PCO}_{\mathbf{2}} \\
\left(\mathrm{mm} \mathrm{H}_{\mathrm{g}}\right)\end{array}$ & $\begin{array}{l}\text { Urea } \\
(\mathrm{mgl} \\
100 \mathrm{ml})\end{array}$ \\
\hline \multirow{7}{*}{$\begin{array}{l}\text { Case Records MGH } \\
\text { (1953) } \\
\text { Massaro and Owen } \\
\text { (1962) } \\
\text { Fry (1962) } \\
\text { Loebel and Walkoff } \\
\text { (1962) } \\
\text { Breidahl and Ritchie } \\
\text { (1962) } \\
\text { Case Records MGH } \\
\text { (1963) } \\
\text { Lamberg, Pelkonen, } \\
\text { and Frick (1964) } \\
\text { Goldberg et al (1964) }\end{array}$} & \multirow{3}{*}{$\begin{array}{l}\text { Haemangiosarcoma, } \\
\text { liver } \\
\text { Squamous-cell Ca, } \\
\text { bronchus } \\
\text { Squamous-cell Ca, } \\
\text { bronchus }\end{array}$} & $15 \cdot 6$ & $5 \cdot 0$ & $6 \cdot 25$ & 135 & $4 \cdot 4$ & 98 & $28 \cdot 2$ & - & - & 182 \\
\hline & & 20.0 & $3 \cdot 4$ & - & 142 & $5 \cdot 3$ & 98 & 30 & - & - & 66 \\
\hline & & $15 \cdot 0$ & $2 \cdot 5$ & - & 132 & $3 \cdot 7$ & 100 & 25 & - & - & 51 \\
\hline & $\begin{array}{l}\text { bladder } \\
\text { Dysgerminoma }\end{array}$ & $13 \cdot 3$ & $4 \cdot 6$ & - & 123 & $3 \cdot 8$ & 84 & 27.9 & - & - & 90 \\
\hline & & $17 \cdot 8$ & 0.69 & 'Normal' & 140 & $3 \cdot 0$ & 93 & 31 & - & - & 65 \\
\hline & $\begin{array}{l}\text { colon' } \\
\text { Clear-cell } \mathrm{Ca}, \text { kidney }\end{array}$ & $18 \cdot 6$ & 2.0 & 5.7 & 135 & $4 \cdot 0$ & 97 & 33 & - & - & 77 \\
\hline & Adenocarcinoma, & $12 \cdot 7$ & $1 \cdot 7$ & $6 \cdot 3$ & 138 & - & 95 & - & $7 \cdot 445$ & $46 \cdot 4$ & - \\
\hline \multirow{3}{*}{$\begin{array}{l}\text { Anderson and Glenn } \\
\text { (1965) } \\
\text { O'Grady et al (1965) } \\
\text { Keller, Goldschneider, } \\
\text { and Lafferty (1965) } \\
\text { Marks (1965) }\end{array}$} & $\begin{array}{l}\text { kidney }^{\mathbf{1}} \\
\text { Squamous-cell Ca, }\end{array}$ & 12.0 & $2 \cdot 0$ & - & 135 & $4 \cdot 1$ & 103 & $26 \cdot 8$ & $7 \cdot 47$ & $36 \cdot 5$ & 52 \\
\hline & $\begin{array}{l}\text { penis } \\
\text { Clear-cell } \mathrm{Ca} \text {, kidney' } \\
\text { Liver cell } \mathrm{Ca}\end{array}$ & $\begin{array}{l}12 \cdot 6 \\
15 \cdot 0\end{array}$ & $\begin{array}{l}3 \cdot 4 \\
4 \cdot 5\end{array}$ & $\begin{array}{l}6 \cdot 4 \\
5 \cdot 2\end{array}$ & $\begin{array}{l}138 \\
134\end{array}$ & $\begin{array}{l}4 \cdot 5 \\
4 \cdot 0\end{array}$ & $\begin{array}{r}103 \\
96\end{array}$ & $\begin{array}{l}28 \\
31\end{array}$ & $\overline{\text { (see text) }}$ & - & $\begin{array}{r}34 \\
128\end{array}$ \\
\hline & Adenocarcinoma, & $20 \cdot 2$ & $4 \cdot 4$ & 8.0 & 142 & $5 \cdot 5$ & 98 & 27 & - & - & 73 \\
\hline \multirow{7}{*}{$\begin{array}{l}\text { Gault and Kinsella } \\
\text { (1965) } \\
\text { Turkington, Goldman, } \\
\text { Ruffner, and Dobson } \\
\text { (1966) } \\
\text { Strickland, Bold, and } \\
\text { Medd (1967) } \\
\text { Cabau, Dubost, and } \\
\text { Leprat (1968) } \\
\text { Ross and Shelley } \\
\text { (1968) } \\
\text { Dean, Lambie, and } \\
\text { Shivas (1969) } \\
\text { Menguy (1969) }\end{array}$} & $\begin{array}{l}\text { pancreas } \\
\text { Squamous-cell Ca, }\end{array}$ & $17 \cdot 0$ & $2 \cdot 7$ & $7 \cdot 5$ & 137 & 3.8 & 92 & 34 & - & - & - \\
\hline & $\begin{array}{l}\text { bronchus } \\
\text { Squamous-cell Ca, } \\
\text { bronchus }\end{array}$ & $16 \cdot 6$ & $2 \cdot 5$ & 6.8 & 136 & $2 \cdot 2$ & $87 \cdot 8$ & 43 & $7 \cdot 52$ & - & 39 \\
\hline & Anaplastic $\mathbf{C a}$, & $15 \cdot 1$ & $3 \cdot 2$ & $5 \cdot 7$ & 135 & $4 \cdot 8$ & 90 & 32 & - & - & 45 \\
\hline & $\begin{array}{l}\text { bronchus } \\
\text { Retroperitoneal }\end{array}$ & $16 \cdot 4$ & - & $7 \cdot 8$ & 144 & 3.6 & 94 & 34 & - & - & 28 \\
\hline & $\begin{array}{l}\text { fibrosarcoma } \\
\text { Mesonephric Ca, }\end{array}$ & $17 \cdot 0$ & $5 \cdot 2$ & - & 130 & $2 \cdot 7$ & 87 & 27 & - & - & 190 \\
\hline & $\begin{array}{l}\text { ovary } \\
\text { Squamous-cell Ca, }\end{array}$ & $15 \cdot 3$ & $1 \cdot 2$ & $5 \cdot 82$ & 140 & $2 \cdot 4$ & 93 & $27 \cdot 5$ & - & - & 77 \\
\hline & $\begin{array}{l}\text { kidney } \\
\text { Melanosarcoma }\end{array}$ & $\begin{array}{l}13 \cdot 4 \\
14 \cdot 6\end{array}$ & 'Low' & $\begin{array}{l}7 \cdot 0 \\
6.7\end{array}$ & $\begin{array}{l}136 \\
137\end{array}$ & $\begin{array}{l}3 \cdot 7 \\
4 \cdot 9\end{array}$ & $\begin{array}{l}97 \\
96\end{array}$ & $\begin{array}{l}22 \cdot 5 \\
27\end{array}$ & - & $\underline{-}$ & $\frac{46}{-}$ \\
\hline
\end{tabular}

Table V Details of patients with 'pseudohyperparathyroidism' from the literature

${ }^{1}$ Cases in which a parathyroid-like-polypeptide was identified in either the primary tumour or a metastasis.

'Estimation not mentioned in case report. 
of 102 m-equiv per litre (values of $103 \mathrm{~m}$-equiv per litre in both cases). In one of these two cases (that of Goldberg, Tashjian, Order, and Dammin, 1964) there was a proven metabolic alkalosis (arterial blood $p \mathrm{H} 7 \cdot 47, \mathrm{PCO}_{2} 36.5 \mathrm{mmHg}$ and plasma bicarbonate concentration of $26.8 \mathrm{~m}$-equiv per litre). In two of the other reported cases the metabolic alkalosis was proven by blood $p \mathrm{H}$ values. In the case reported by O'Grady, Morse, and Lee (1965) the arterial blood $p \mathrm{H}$ was $7 \cdot 54$, and bicarbonate concentration $38 \mathrm{~m}$-equiv per litre on the third day in hospital, the values shown in Table $\mathrm{V}$ being the values on admission. In all of the other cases detailed in Table $\mathrm{V}$ the findings were consistent with a metabolic alkalosis as shown by a low plasma chloride and increased bicarbonate concentration, the latter in many of the cases despite an increased blood urea concentration. In their recent study of eight patients with bronchial carcinoma and hypercalcaemia, none of whom had bone metastases, Azzopardi and Whittaker (1969) reported that in six of them the hypercalcaemia was associated with a hypocalcaemic alkalosis, as reflected by low plasma potassium and high bicarbonate concentrations. No values were reported for the concentration of other plasma electrolytes or blood $p \mathrm{H}$ or $\mathrm{PCO}_{2}$ status in their study. From the findings in the patient reported here and those from the literature it could be postulated that the parathyroid-hormone-like substance identified in malignant tumours either differs in its biological activity from the naturally occurring hormone or is associated with other polypeptide hormone production which allows the hypercalcaemia it causes to be differentiated from that due to primary hyperparathyroidism. Metabolic alkalosis is an established biochemical feature of Cushing's syndrome and the excessive endogenous secretion of cortisol, and, in patients with this syndrome associated with carcinoma of the bronchus, this has been attributed to the secretion by the tumour cells of a polypeptide with an ACTH-like activity. However, in these patients the primary neoplasm is most commonly an oat-cell carcinoma of the bronchus (O'Riordan, Blanshard, Moxham, and Nabarro, 1966), while parathyroid-hormone-like polypeptide activity is usually associated with tumours of squamous cell origin (Table V). Verification of the hypothesis that the tumour cells in patients with 'pseudo-hyperparathyroidism' secrete two substances would require assay of tumour extracts from these patients for polypeptides with both parathyroidhormone-like and ACTH-like activity.

The differential diagnosis of hypercalcaemia is based essentially on biochemical criteria as the symptoms of hypercalcaemia are the same irrespective of the aetiological mechanism. Of the wide variety of tests that are available for differentiating the hypercalcaemia of primary hyperparathyroidism from that due to all other causes (Wills, 1970) the only one that we have found of value is the cortisone suppression test (Dent, 1956; Dent and Watson, 1968). Even this test is, however, not completely reliable as both suppression of the hypercalcaemia of primary hyperparathyroidism and non-suppression of that due to other causes has been reported (Dent, 1962; Pyrah et al, 1966; Avioli, 1968; Strott and Nugent, 1968; Garcia and Yendt, 1968). The changes in plasma chloride concentration and acidbase status in patients with hypercalcaemia appear to offer a valuable index in the differentiation of the patients with hypercalcaemia due to primary hyperparathyroidism from those with hypercalcaemia due to all other causes.

References

Albright, F., and Reifenstein, E. C., Jr. (1948). The Parathyroid Glands and Metabolic Bone Disease. Williams and Wilkins, Baltimore. Baillière, London.

Anderson, E. E., and Glenn, J. F. (1965). Penile malignancy and hypercalcemia. J. Amer. med. Ass., 192, 328-329.

Ardaillou, R., Amiel, C., Lecestre, M., and Richet, G. (1963). Acidification de l'urine après injection intra-veineuse de gluconate de calcium à l'homme. IV. Effets opposés de l'acétazolamide et du gluconate de calcium. Rev. franc. Etud. clin. biol., 8, 681-687.

Ardaillou, R., Vuagnat, P., Milhaud, G., and Richet, G. (1967) Effets de la thyrocalcitonine sur l'excrétion rénale des phosphates, du calcium et des ions $\mathrm{H}^{+}$chez l'homme. Nephron, 4, 298-314.

Avioli, L. V. (1968). The diagnosis of primary hyperparathyroidism. Med. Clin. N. Amer., 52, 451-462.

Azzopardi, J. G., and Whittaker, R. S. (1969). Bronchial carcinoma and hypercalcaemia. J. clin. Path., 22, 718-724.

Barzel, U. S. (1969). Systemic alkalosis in hypoparathyroidism. J. clin. Endocr., 29, 917-918.

Breidahl, H. D., and Ritchie, B. C. (1962). Hypercalcaemia due to malignant ovarian tumour. A case report. Med J. Aust., 1, 208-210.

Cabau, A., Dubost, C., and Leprat, J. (1968). Les hypercalcémies dites 'paranéoplasiques'. Rev. franc. Endocr. clin., 9, 213-228.

Cochran, M., Peacock, M., Sachs, G., and Nordin, B. E. C. (1970). Renal effects of calcitonin. Brit. med. J., 1, 135-137.

Dean, A. C. B., Lambie, A. T., and Shivas, A. A. (1969). Hypercalcaemic crisis and squamous carcinoma of the renal pelvis. Brit. J. Surg., 56, 375-379.

Dent, C. E. (1956). Cortisone test for hyperparathyroidism. Brit. med. J., $1,230$.

Dent, C. E. (1962). Some problems of hyperparathyroidism. Brit. med. J., 2, 1419-1425 and 1495-1500.

Dent, C. E., and Watson, L. (1968). The hydrocortisone test in primary and tertiary hyperparathyroidism. Lancet, 2, 662-664.

Fiske, C. H., and Subbarow, Y. (1925). The colorimetric determination of phosphorus. J. biol. Chem., 66, 375-400.

Fry, L. (1962). Pseudohyperparathyroidism with carcinoma of bronchus. Brit. med. J., 1, 301-302.

Garcia, D. A., and Yendt, E. R. (1968). Temporary remission of hypercalcemia in hyperparathyroidism induced by corticosteroids. Canad. Med. Ass. J., 99, 1047-1050.

Gault, M. H., and Kinsella, T. D. (1965). Carcinoma of lung with adrenal hyperfunction and hypercalcemia treated by parathyroidectomy. Canad. med. Ass. J., 92, 317-324.

Goldberg, M. F., Tashjian, A. H., Jr., Order, S. E., and Dammin, G. J. (1964). Renal adenocarcinoma containing a parathyroid hormone-like substance and associated with marked hypercalcaemia. Amer. J. Med., 36, 805-814.

Heffernan, A. G. A., and Carty, H. M. L. (1969). Detection of hyperparathyroidism. Brit. med. J., 3, 783. 
Heinemann, H. O. (1965). Metabolic alkalosis in patients with hypercalcemia. Metabolism, 14, 1137-1152.

Hellman, D. E., Au, W. Y. W., and Bartter, F. C. (1965). Evidence for a direct effect of parathyroid hormone on urinary acidification. Amer. J. Physiol., 209, 643-650.

Howard, J. E. (1962). Normal and abnormal function of the parathyroids. Trans. Coll. Phycns Philad., 30, 55-65.

Keller, R. T., Goldschneider, I., and Lafferty, F. W. (1965). Hypercalcemia secondary to a primary hepatoma. J. Amer. med. Ass., 192, 782-784.

Lafferty, F. W. (1966). Pseudohyperparathyroidism. Medicine, Baltimore, 45, 247-260.

Lamberg, B.-A., Pelkonen, R., and Frick, M. H. (1964). Hypercalcaemia in renal carcinoma. Acta med. scand., 176, 187-194.

Lewin, M. R., Wills, M. R., and Baron, D. N. (1969). The ultramicrofluorimetric determination of calcium in plasma. J. clin. Path., 22, 222-225.

Loebel, A. S., and Walkoff, C. S. (1962). Hypercalcemia in neoplastic disease without bone metastatses. N.Y.St.J. Med., 62, 101-104.

Marks, C. (1965). Hypercalcemia in malignant non-parathyroid disease. Amer. Surg., 31, 254-258.

Massachusetts General Hospital (1953). Case record 39061. Haemangiosarcoma of liver, with metastases to right adrenal gland. New Engl. J. Med., 248, 248-254.

Massachusetts General Hospital (1963). Case record 63-1963. Adenocarcinoma of transverse colon arising in villous adenoma, with extensive metastases to liver and parathormonelike activity. New Engl. J. Med., 269, 801-808.

Massaro, D. J., and Owen, J. A., Jr. (1962). Persistent hypercalcemia associated with bronchogenic carcinoma and primary chiefcell hyperplasia of the parathyroids. Amer. Rev. resp. Dis., 85, 727-734.

Menguy, R. (1969). Pseudohyperparathyroidism due to malignant melanoma. Surg. Clin. N. Amer. 49, 49-56.

Natelson, S. (1951). Routine use of ultramicro methods in the clinical laboratory, Amer, J clin. Path, 21, 1153-1172.

Nordin, B. E. C. (1960). The effect of intravenous parathyroid extract on urinary $p \mathrm{H}$, bicarbonate and electrolyte excretion. Clin. Sci., 19, 311-319.

O'Grady, A. S., Morse, L. J., and Lee, J. B. (1965). Parathyroid hormone-secreting renal carcinoma associated with hypercalcemia and metabolic alkalosis. Ann. intern. Med., 63, 858-868.

O'Riordan, J. L. H., Blanshard, G. P., Moxham, A., and Nabarro, J. D. N. (1966). Corticotrophin-secreting carcinomas. Quart. J. Med., 35, 137-147.

Pyrah, L. N., Hodgkinson, A., and Anderson, C. K. (1966). Primary hyperparathyroidism. Brit. J. Surg., 53, 245-316.

Richet, G., Ardaillou, R., Amiel, C., and Lecestre, M. (1962). Acidi- fication des urines et augmentation de l'ammoniurie après injection intravenineuse de gluconate de calcium chez l'homme. Rev. frans. Etud. clin. biol., 7, 355-361.

Richet, G., Ardaillou, R., Amiel, C., and Lecestre, M. (1963). Acidification de l'urine par injection intraveineuse de sels de calcium. J. Urol. Nephrol., 69, 373-398.

Ross, L., and Shelley, E. (1968). Mesonephric carcinoma of the ovary producing hypercalcemia. Amer.J. Obstet. Gynec., 100, 418-421.

Singer, F. R, Woodhouse, N. J, Y, Parkinson, D. K, and Joplin, G. F. (1969). Some acute effects of administered porcine calcitonin in man. Clin. Sci., 37, 181-190.

Snedecor, P. A., and Baker, H. W. (1964). Pseudohyperparathyroidism due to malignant tumors. Cancer (Philad.), 17, 1492-1496.

Strickland, N. J., Bold, A. M., and Medd, W. E. (1967). Bronchial carcinoma with hypercalcaemia simulating cerebral metastases. Brit. med. J., 3, 590-592.

Strott, C. A., and Nugent, C. A. (1968). Laboratory tests in the diagnosis of hyperparathyroidism in hypercalcemic patients. Ann. intern. Med., 68, 188-202.

Thomas, W. C., Jr., Connor, T. B., and Morgan, H. G. (1958). Some observations on patients with hypercalcemia exemplifying problems in differential diagnosis, especially in hyperparathyroidism. J. Lab. clin. Med., 52, 11-19.

Turkington, R. W., Goldman, J. K., Ruffner, B. W., and Dobson, J. L. (1966). Bronchogenic carcinoma simulating hyperparathyroidism. Cancer (Philad.), 19, 406-414.

Verbanck, M. (1965). Le fonctionnement du rein dans les etats d'hypercalcemie. Acta clin. belg., Suppl. 1, 1-130.

Wills, M. R. (1964). Excretion of Urinary Calcium with particular Reference to the Renal Action of Parathyroid Hormone. MD Thesis, Bristol.

Wills, M. R. (1970). Laboratory tests in the differentiation of hyperparathyroidism from other causes of hypercalcaemia. Ann. clin. Biochem., 7, 136-140.

Wills, M. R., and Gray, B. C. (1964). Micro-method for the estimation of calcium by Autoanalyzer. J. clin. Path., 17, 687-689.

Wills, M. R., and McGowan, G. K. (1963). Hyperchloraemia as a diagnostic feature in hyperparathyroidism. J. Bone Jt Surg., 45B, 799.

Wills, M. R., and McGowan, G. K. (1964a). Plasma chloride levels in hyperparathyroidism and other hypercalcaemic states. Brit. med.J., 1, 1153-1156.

Wills, M. R., and McGowan, G. K. (1964b). Acid-base disturbances in hypercalcaemia. J. clin. Path., 17, 476.

Wolfson, W. Q., Cohn, C., Calvary, E., and Ichiba, F. (1948). Studies in serum proteins. V. A rapid procedure for the estimation of total protein, true albumin, total globulin, alpha globulin, beta globulin and gamma globulin in $1.0 \mathrm{ml}$ of serum. Amer. $J$. clin. Path., 18, 723-730. 